\title{
Molecular characterization of field isolates of Pseudomonas syringae pv. glycinea differing in coronatine production
}

\author{
Matthias Ullrich, ${ }^{1,2 *}$ Stefan Bereswill, ${ }^{1}$ Beate VölksCh, ${ }^{2}$ Wolfgang Fritsche ${ }^{2}$ \\ and KLAUS GeIDER ${ }^{1}$ \\ ${ }^{1}$ Max-Planck-Institut für medizinische Forschung, Jahnstraße 29, D-69028 Heidelberg, Germany \\ ${ }^{2}$ Institut für Mikrobiologie, Universität Jena, Philosophenweg 12, D-07743 Jena, Germany
}

(Received 17 July 1992; revised 6 April 1993; accepted 26 April 1993)

\begin{abstract}
Coronatine-producing and non-producing strains of Pseudomonas syringae pv. glycinea have been examined. We found a connection between copper resistance and synthesis of coronatine. Published data implied that these properties may be encoded on different plasmids. Production of coronatine and copper resistance were also found to be correlated for pv. glycinea in 19 field-isolates from leaf spots of plants in a soybean field and in 28 strains of a bacterial culture collection. Genomic diversity within pv. glycinea was investigated by plasmid profiling, DNA hybridization studies and PCR analysis. All strains unable to produce coronatine (cor ${ }^{-}$) were sensitive to copper ions and showed no homology to DNA from plasmid pSAY1, which carries a gene cluster for steps in coronatine production. In addition, cor $^{-}$strains could be distinguished from coronatine-producing strains by a single unique band when amplified by random primer PCR. Plasmid profiles of strains isolated from field-populations during 1983, 1985 and 1990 showed that coronatine-producing and non-producing strains were present. The plasmid patterns also varied in 28 strains examined from a culture collection. No correlation between plasmid patterns and race specificity was observed. Cosmid pSAY1 proved to be an effective probe for detection of the coronatine synthesis genes and also revealed polymorphisms in coronatine producing strains of pv. glycinea.
\end{abstract}

\section{Introduction}

Pseudomonas syringae pv. glycinea, which causes bacterial blight of soybean [Glycine max (L.) Merrit], can produce the phytotoxin coronatine. Other pathovars of $P$. syringae producing this toxin are pv. atropurpurea (Nishiyama et al., 1976), pv. morsprunorum (Mitchell, 1982), and pv. tomato (Bender et al., 1987), which are pathogenic to ryegrass, Prunus spp. and tomato, respectively. Recently, analogues of coronatine were shown to be produced by Xanthomonas campestris pv. phormiicola, a pathogen of New Zealand flax (Mitchell, 1991). Coronatine induces chlorosis, hypertrophy and stunting of plant tissue. It has an unusual structure consisting of a bicyclic moiety, coronafacic acid, which is coupled to an ethylcyclopropyl amino acid, coronamic acid. The biosynthetic pathway of this phytotoxin has

*Author for correspondence. Tel. 496203106117 ; fax 496203106 122.

Abbreviation: HR, hypersensitive reaction. been partially determined (Mitchell, 1985; Parry et al., 1991; Parry \& Mafoti, 1986; Young et al., 1992).

Although coronatine is not a pathogenicity factor, several reports have shown that synthesis of the phytotoxin enhances the virulence of producing bacteria and therefore contributes to the biological fitness of pathogens in planta (Bender et al., 1987; Gnanamanickam et al., 1982; Sato et al., 1983). Little is known about natural field-populations of $P$. syringae with respect to coronatine production. A study of coronatine synthesis in vitro and in planta revealed that 7 out of 19 pathogenic strains of $P$. syringae pv. glycinea did not produce coronatine (Gnanamanickam et al., 1982). It was suggested that the negative strains produced another heat-stable factor which inhibits the growth of Escherichia coli cells. This inhibition could be reversed by arginine or citrulline, a feature characteristic of phaseolotoxin production in $P$. syringae pv. phaseolicola (Staskawicz \& Panopoulos, 1979). Genes required for coronatine production have been linked to plasmid DNA in at least four pathovars (Sato et al., 1983; Bender et al., 1989, 1991). Recently, a $34 \mathrm{~kb}$ cloned region of 
plasmid p4180A in $P$. syringae pv. glycinea PG4180 was saturated with $\mathrm{Tn} 5$, and $27 \mathrm{~kb}$ were shown to be required for coronatine production (Young et al., 1992). Furthermore, mutants of strain PG4180 deficient in steps of toxin biosynthesis could be complemented in feeding experiments by addition of coronatine precursors (Young et al., 1992). In $P$. syringae pv. tomato strain DC3000, steps for coronatine production were found to be chromosomally encoded and have been cloned in cosmid pEC18 (Ma et al., 1991). Interestingly, pEC18 showed homology to three SstI fragments of pSAY1 (C. Bender, personal communication).

In $P$. syringae pv. tomato, the cop genes determining copper resistance are plasmid-encoded. In strain PT23.2, resistance was associated with pTC23C $(67 \mathrm{~kb})$ and pPT23D (35 kb). Both plasmids transferred copper resistance by forming a cointegrate which resembled in size the $100 \mathrm{~kb}$ plasmid involved in coronatine synthesis (Bender \& Cooksey, 1986, 1987). Recently, two periplasmic proteins, CopA $(72 \mathrm{kDa})$ and CopC $(12 \mathrm{kDa})$, and the outer-membrane protein CopB $(39 \mathrm{kDa})$ were found to mediate copper resistance in $P$. syringae pv. tomato by sequestration of copper ions in the periplasm, thereby preventing the entry of the toxic $\mathrm{Cu}^{2+}$ ions into the cytoplasm (Cha \& Cooksey, 1991). It has been suggested that copper resistance and coronatine synthesis are encoded on different plasmids (Bender \& Cooksey, 1986; Bender et al., 1989).

In various pathovars of $P$. syringae and $X$. campestris, specific races have been established (Cross et al., 1966; Fett \& Sequeira, 1981; Cook \& Stall, 1982). Hostcompatible races of phytopathogenic bacteria are characterized by their ability to overcome plant defence mechanisms and produce disease symptoms in certain host cultivars. In resistant cultivars, early recognition causes a hypersensitive reaction (HR). The molecular basis for this taxonomic differentiation within pathovars is the gene-to-gene relationship of dominant plant disease resistance genes and dominant avirulence genes in the bacteria (Keen \& Staskawicz, 1988). In X. campestris pv. vesicatoria copper resistance and avirulence loci were reported to be linked on a large plasmid (Stall et al., 1986). However, in P. syringae pv. glycinea the correlation between phytotoxin production, copper resistance and race-specificity is not known.

In the current study we investigated the ecologically relevant phytotoxin production in field isolates of $P$. syringae pv. glycinea using a bioassay for coronatine and by Southern blot analysis using a DNA probe containing coronatine synthesis genes from $P$. syringae pv. tomato (Bender et al., 1991). P. syringae pv. glycinea strains were also examined for differences in plasmid profiles, race affiliation, and tolerance to $\mathrm{CuSO}_{4}$. The correlation of coronatine synthesis and copper resistance described here also provides a convenient tool to monitor coronatinepositive strains of $P$. syringae pv. glycinea by growth on media with $\mathrm{CuSO}_{4}$.

A PCR amplification method using a randomsynthesized oligonucleotide primer has been used not only for identification of organisms (Welsh \& McClelland, 1990; Williams et al., 1990; Welsh et al., 1991; Martin et al., 1991), but also for the discrimination of pathogenic and non-pathogenic fungi (Schäfer \& Wöstemeyer, 1992). The latter approach was applied here to distinguish coronatine producing and nonproducing strains of pv. glycinea. A preliminary report on plasmid profiles and coronatine production in $P$. syringae pv. glycinea strains has been published elsewhere (Ullrich et al., 1991).

\section{Methods}

Bacterial strains and plasmids. During the 1990 growing season $P$. syringae pv. glycinea cultures were isolated from field grown plants of soybean cv. Maple Arrow at Dornburg near Jena, Germany. At each isolation date, three to five leaf spots with necrotic lesions surrounded by chlorotic haloes were excised with a corkborer ( $7 \mathrm{~mm}$ diam.), surface sterilized in $70 \%(\mathrm{v} / \mathrm{v})$ ethanol, washed three times in sterile water and macerated. Homogenates were dissolved in $1 \mathrm{ml} 0.9 \% \mathrm{NaCl}$ and serially diluted for plating on King's medium B agar (King et al., 1954). After 3-4 d incubation at $28^{\circ} \mathrm{C}$, colonies typical for $P$. syringae were identified by microscopic, physiological and biochemical tests (Bradbury, 1988; B. Völksch et al., unpublished data), including pigment production (King et al., 1954), the LOPAT tests and nitrate reduction (Lelliott et al., 1966), and the Hugh-Leifson test (Hugh \& Leifson, 1953). Strains characterized as fluorescent pseudomonads were tested for pathogenicity on 20-d-old plants of soybean cv. Maple Arrow. Symptom-producing isolates were assigned as $\boldsymbol{P}$. syringae pv. glycinea and one strain per leaf spot was stored for future experiments (Table 1). Strains from various geographic origins were obtained from the Göttinger Sammlung Phytopathogener Bakterien (GSPB; Institut für Pflanzenpathologie und Pflanzenschutz der Universität Göttingen, Germany) (Table 1). Additionally, reference strains of $\boldsymbol{P}$. syringae pv. glycinea were obtained from the bacterial culture collection at the University of Jena (Institut für Mikrobiologie). P. syringae pv. syringae PS61 is a copper-sensitive, non-producer of coronatine which has been described by Bender \& Cooksey (1986) and Bender et al. (1989). P. syringae pv. syringae PS61(p4180A) produces coronatine and was constructed previously by transforming the coronatine plasmid $\mathrm{p} 4180 \mathrm{~A}$, which resides in P. syringae pv. glycinea PG4180, into PS61 by electroporation (Young, 1991).

$P$. syringae strains were propagated on standard I (Merck) or on King's medium B agar plates at $28^{\circ} \mathrm{C}$. Escherichia coli was grown on standard I agar or on Luria-Bertani (LB) solidified medium at $37^{\circ} \mathrm{C}$. If required for plasmid selection, tetracycline was added to media at $25 \mu \mathrm{g} \mathrm{m}^{-1}$. For plasmid isolation the strains were grown in LB medium. Plasmid pSAY1 $(52 \mathrm{~kb})$ was generously provided by Dr C. L. Bender, Stillwater, Oklahoma, USA.

Preparation and hybridization of plasmid DNA. Plasmids were isolated after alkaline lysis of the cells according to the Qiagen procedure (DIAGEN). The DNA was analysed on $0.8 \%$ agarose gels at $120 \mathrm{~V}$ for $2 \mathrm{~h}$ in the case of whole plasmids and at $25 \mathrm{~V}$ for $18 \mathrm{~h}$ for restriction fragments. Restriction digests and Southern transfers were done by standard procedures (Maniatis et al., 1982). The nylon filters 


\section{Table 1. Sources and properties of $P$. syringae pv. glycinea strains}

Coronatine phenotypes were determined by the potato hypertrophy assay. The $\mathrm{MIC}$ of $\mathrm{CuSO}_{4}$ was defined as the minimal concentration which inhibited confluent growth of the bacterial culture after incubation at $28^{\circ} \mathrm{C}$ for $72 \mathrm{~h}$. Strains resistant to $2 \mathrm{mM}^{-\mathrm{Cu}^{2+}}$ are indicated. GSPB strains were obtained from the Göttinger Sammlung Phytopathogener Bakterien. Plasmid pSAY1 carries genes required for coronatine synthesis (Bender et al., 1991).

\begin{tabular}{|c|c|c|c|c|c|c|}
\hline Strain & $\begin{array}{l}\text { Year of } \\
\text { isolation* }\end{array}$ & $\begin{array}{l}\text { Coronatine } \\
\text { phenotype }\end{array}$ & $\mathrm{MIC}$ of $\mathrm{CuSO}_{4}$ & $\begin{array}{l}\text { DNA homology } \\
\text { to pSAY1 }\end{array}$ & Race* & Source \\
\hline GSPB 67 & 1943 & cor $^{-}$ & $0.4 \mathrm{~mm}$ & - & $?$ & Canada \\
\hline GSPB 472 & 1951 & cor $^{-}$ & $0.4 \mathrm{~mm}$ & - & $?$ & USA \\
\hline GSPB 1201 & $?$ & $\operatorname{cor}^{-}$ & $0.6 \mathrm{mM}$ & - & 2 & Race reference \\
\hline GSPB 1545 & 1985 & cor $^{+}$ & resistant & + & 4 & Zaire \\
\hline GSPB 1548 & 1985 & $\operatorname{cor}^{+}$ & resistant & + & 4 & Rwanda \\
\hline GSPB 1565 & 1984 & $\operatorname{cor}^{+}$ & resistant & + & 4 & Hungary \\
\hline GSPB 1834 & $?$ & cor $^{-}$ & $0.4 \mathrm{~mm}$ & - & 0 & Race reference \\
\hline GSPB 1835 & $?$ & $\operatorname{cor}^{-}$ & $0.4 \mathrm{~mm}$ & - & 1 & Race reference \\
\hline GSPB 1837 & $?$ & cor $^{-}$ & $0.4 \mathrm{~mm}$ & - & 5 & Race reference \\
\hline GSPB 1971 (SB1ab) & 1989 & $\operatorname{cor}^{+}$ & resistant & + & 4 & Race reference \\
\hline GSPB 1974 (Lab-a) & 1990 & $\operatorname{cor}^{+}$ & resistant & + & 6 & Race reference \\
\hline GSPB 1985 (SJ130-1) & 1990 & cor $^{-}$ & $0.4 \mathrm{~mm}$ & - & 9 & France \\
\hline GSPB 1988 (SJ309-17) & 1990 & $\operatorname{cor}^{+}$ & resistant & + & 4 & France \\
\hline GSPB 1993 (IPVBO 1479) & 1983 & cor $^{+}$ & resistant & + & 4 & Italy \\
\hline GSPB 1994 (IPVBO 1481) & 1982 & $\operatorname{cor}^{+}$ & resistant & + & 4 & Italy \\
\hline GSPB 1995 (IPVBO 2116) & 1985 & $\operatorname{cor}^{-}$ & $0.6 \mathrm{~mm}$ & - & 4 & Italy \\
\hline GSPB 1996 (S-1) & 1983 & cor $^{-}$ & $0.6 \mathrm{~mm}$ & - & 4 & Serbia \\
\hline GSPB 1997 (S-49) & 1983 & cor $^{-}$ & $0.6 \mathrm{~mm}$ & - & $\mathbf{X}$ & Race reference \\
\hline GSPB 1999 (1B-PL) & 1990 & $\operatorname{cor}^{+}$ & resistant & + & 4 & Poland \\
\hline GSPB 2001 (4B2b-PL) & 1990 & $\operatorname{cor}^{+}$ & resistant & + & 4 & Poland \\
\hline GSPB 2002 (H-1a) & 1990 & $\operatorname{cor}^{+}$ & resistant & + & 4 & Hungary \\
\hline GSPB $2003(\mathrm{H}-3 \mathrm{c})$ & 1990 & cor $^{-}$ & $0.4 \mathrm{~mm}$ & - & 9 & Hungary \\
\hline GSPB 2004 & $?$ & $\operatorname{cor}^{-}$ & $0.4 \mathrm{~mm}$ & - & 9 & Race reference \\
\hline GSPB $2005(H-7 a)$ & 1990 & cor $^{+}$ & resistant & + & 6 & Hungary \\
\hline GSPB 2006 (1d) & 1980 & cor $^{-}$ & $0.4 \mathrm{~mm}$ & - & $\mathbf{X}$ & Hungary \\
\hline GSPB 2033 (Bar-a) & 1990 & $\operatorname{cor}^{+}$ & resistant & + & 4 & Germany \\
\hline GSPB 2034 (1561) & $?$ & cor $^{-}$ & $0.4 \mathrm{~mm}$ & - & 4 & France \\
\hline PG 4180 & 1975 & cor $^{+}$ & resistant & + & 4 & New Zealand \\
\hline Psg 7a/90 & 1990 & cor $^{+}$ & resistant & + & 4 & This study \\
\hline Psg $15 \mathrm{a} / 90$ & 1990 & cor $^{+}$ & resistant & + & 4 & This study \\
\hline Psg 16a/90 & 1990 & cor $^{-}$ & $0.6 \mathrm{~mm}$ & - & 9 & This study \\
\hline Psg $18 \mathrm{a} / 90$ & 1990 & cor & $0.6 \mathrm{~mm}$ & - & 9 & This study \\
\hline Psg 24a/90 & 1990 & cor $^{-}$ & $0.6 \mathrm{~mm}$ & - & 9 & This study \\
\hline Psg 27a/90 & 1990 & cor $^{-}$ & $0.6 \mathrm{~mm}$ & - & 9 & This study \\
\hline Psg 28a/90 & 1990 & $\operatorname{cor}^{+}$ & resistant & + & 4 & This study \\
\hline Psg 34a/90 & 1990 & cor $^{-}$ & $1 \cdot 2 \mathrm{~mm}$ & - & $?$ & This study \\
\hline Psg 36a/90 & 1990 & cor $^{-}$ & $0.6 \mathrm{~mm}$ & - & $?$ & This study \\
\hline Psg 43a/90 & 1990 & $\operatorname{cor}^{+}$ & resistant & + & 4 & This study \\
\hline Psg 44a/90 & 1990 & $\operatorname{cor}^{-}$ & $0.6 \mathrm{~mm}$ & - & 9 & This study \\
\hline Psg 46a/90 & 1990 & $\mathrm{cor}^{+}$ & resistant & + & 4 & This study \\
\hline Psg 49a/90 & 1990 & $\operatorname{cor}^{+}$ & resistant & + & 4 & This study \\
\hline Psg 51a/90 & 1990 & $\operatorname{cor}^{-}$ & $0.6 \mathrm{~mm}$ & - & $?$ & This study \\
\hline Psg 55a/90 & 1990 & cor $^{-}$ & $0.6 \mathrm{~mm}$ & - & $?$ & This study \\
\hline Psg 58a/90 & 1990 & cor $^{+}$ & resistant & + & 4 & This study \\
\hline Psg S8/83 & 1983 & cor $^{+}$ & resistant & + & 4 & This study \\
\hline Psg S30/85 & 1985 & cor $^{+}$ & resistant & + & 4 & This study \\
\hline Psg S161/83 & 1983 & $\operatorname{cor}^{+}$ & resistant & + & 4 & This study \\
\hline
\end{tabular}

*?, unknown isolation date or race.

were prehybridized for $2 \mathrm{~h}$ and hybridized in $5 \times \mathrm{SSC}(1 \times \mathrm{SSC}$ is $0.15 \mathrm{M}-\mathrm{NaCl}$ and $0.015 \mathrm{M}$-sodium citrate), $0.02 \%$ SDS, $0.1 \% \mathrm{~N}$ lauroylsarcosine, and $1 \%(\mathrm{w} / \mathrm{v})$ dried skimmed milk at $68{ }^{\circ} \mathrm{C}$ for $16 \mathrm{~h}$. Post-hybridization washes were twice in $2 \times$ SSC plus $0.1 \%$ SDS at room temperature for $5 \mathrm{~min}$, and twice in $0.1 \times \mathrm{SSC}$ plus $0.1 \%$ SDS at $68^{\circ} \mathrm{C}$ for $15 \mathrm{~min}$. DNA labelling with digoxigenin-11-dUTP and detection of blots were done according to the manufacturer's specifications (Boehringer Mannheim).
Bioassay for coronatine and copper resistance. Coronatine production was assessed by screening strains for their ability to induce hypertrophy on potato tubers using Völksch's (Völksch et al., 1989) modification of Sakai's method (Sakai et al., 1979). Copper resistance was assessed by incubating the cultures for $72 \mathrm{~h}$ at $28^{\circ} \mathrm{C}$ on standard I agar plates containing $\mathrm{CuSO}_{4}$ at concentrations of $0.4,0.6,1.2$ and $2.0 \mathrm{~mm}$. The minimal inhibitory concentration (MIC) of $\mathrm{CuSO}_{4}$ was defined as the lowest concentration which inhibited confluent growth of the bacteria 
after $72 \mathrm{~h}$ incubation at $28^{\circ} \mathrm{C}$. The possible linkage of copper resistance and coronatine production was investigated by assessing growth of $P$. syringae pv. syringae PS61 and PS61(p4180A) on standard I agar containing $2 \cdot 0 \mathrm{mM}-\mathrm{CuSO}_{4}$.

Determination of bacterial races. All strains of $P$. syringae pv. glycinea isolated in this study were tested for their ability to elicit a compatible or incompatible reaction on eight different soybean cultivars: Acme, Bicentennial, Chippewa, Flambeau, Harosoy, Merrit, Norchief and Peking (Cross et al., 1966; Fett \& Sequeira, 1981). Inoculum was prepared from colonies on standard I agar plates, suspended in sterile water, and adjusted to a final concentration of $1 \times 10^{8}$ c.f.u. $\mathrm{ml}^{-1}\left(\mathrm{OD}_{590}\right.$ $0 \cdot 1-0 \cdot 15)$. Trifoliate leaves of 20-d-old soybean plants of the appropriate differential cultivars were inoculated on the underside of the leaf by means of a syringe. Treated plants were then incubated in a greenhouse with artificial neon light (for $12 \mathrm{~h}$ ) at $20^{\circ} \mathrm{C}$ and $70-90 \%$ humidity for 5-7 d. The hypersensitive reaction (incompatible reaction) was generally observed $24-48 \mathrm{~h}$ after inoculation, whereas the compatible reaction was observed at $5-7 \mathrm{~d}$ following inoculation.

Random primer-dependent PCR. The Tn5-derived $17 \mathrm{mer}$ sequence CAGGACGCTACTTGTGT was used as primer to perform PCRdirected fingerprinting of genomic DNA of coronatine-producing and non-producing $P$. syringae pv. glycinea strains. The genomic DNA was prepared by lysozyme/SDS lysis of the cells followed by phenol/ chloroform extraction. The primer was synthesized with a DNA synthesizer (Applied Biosystem 380B), purified by HPLC $(0 \cdot 1 \mathrm{M}$ triethylamine/acetic acid ( $\mathrm{pH} 7.0)$ and acetonitrile; ODS- $\mathrm{C}_{18}$ column, Beckman), and stored in aliquots at $-20^{\circ} \mathrm{C}$. The amplification reactions were performed in volumes of $50 \mu \mathrm{l}$ containing $67 \mathrm{mM}$ Tris/ $\mathrm{HCl}$ (pH 8.8), $1.5 \mathrm{~mm}-\mathrm{MgCl}_{2}, 10 \mathrm{mM}-2$-mercaptoethanol, $160 \mu \mathrm{g}$ bovine serum albumin $\mathrm{ml}^{-1}, 10 \%(\mathrm{v} / \mathrm{v})$ dimethylsulphoxide, $0.2 \mathrm{mM}$ each of dATP, dCTP, dGTP and TTP, $70 \mathrm{ng}$ primer $(12.5 \mathrm{pmol}), 10 \mathrm{ng}$ template DNA and $0.5 \mathrm{U}$ of Tth DNA polymerase (from Thermus thermophilus, Pharmacia). The assays were performed in a liquid temperature bath cycler (H.-P. Vosberg, Max-Planck-Institut, Heidelberg, Germany). The temperature cycles were controlled by a computer program with denaturation at $93^{\circ} \mathrm{C}$ (for $2 \mathrm{~min}$ in the first cycle, then for $1 \mathrm{~min}$ ), primer annealing to the template DNA at $32^{\circ} \mathrm{C}$ for $2 \mathrm{~min}$, and extension steps at $72{ }^{\circ} \mathrm{C}$ for $2 \mathrm{~min}$. After 37 cycles, the amplification products were separated on a $1.5 \%(w / v)$ agarose gel.

\section{Results}

Coronatine production in Pseudomonas syringae pv. glycinea field isolates

During the growing season from June to October 1990, 76 isolates of $P$. syringae pv. glycinea were recovered from 69 necrotic soybean leaf spots surrounded by chlorotic haloes. Of the $76 \mathrm{pv}$. glycinea isolates, 23 failed to produce detectable amounts of coronatine when tested in the potato hypertrophy assay. The other 53 strains produced coronatine at various levels. Coronatineproducing $\left(\right.$ cor $\left.^{+}\right)$and non-producing $\left(\right.$cor $\left.^{-}\right)$phenotypes were obtained throughout the growing season. From these pv. glycinea isolates, seven cor $^{+}$and nine cor ${ }^{-}$ strains were selected for further genetic studies. The cor $^{-}$ strains were also able to cause formation of small haloes, which were not significantly different from haloes of cor $^{+}$ strains. The nature of this effect is unclear, since we eliminated the possible production of phaseolotoxin-like substances for the coronatine-negative pv. glycinea strains examined in this study. None of the coronatinenegative strains inhibited growth of $E$. coli, Chlorella pyrenoidosa, or Geotrichum candidum in bioassays (B. Völksch \& M. Ullrich, unpublished data).

\section{Plasmid profiles of various coronatine-producing and non-producing $P$. syringae pv. glycinea strains}

Plasmid DNA was purified from sixteen strains isolated in 1990 and three cor ${ }^{+}$pv. glycinea strains which were isolated from the same soybean field in 1983 and 1985 (Fig. 1a). Plasmid DNA was also isolated from cor $^{+}$ strain PG4180. Plasmids could be grouped into four size classes ranging from 70 to $100 \mathrm{~kb}$ (class $\mathrm{A}$ ), 30 to $60 \mathrm{~kb}$ (class $\mathrm{B}$ ), 11 to $15 \mathrm{~kb}$ (class $\mathrm{C}$ ), and $8 \mathrm{~kb}$ (class $\mathrm{D}$ ) (Table 2). Classes A, B and C contained plasmids of more than one size. Subclasses were accordingly designated as A1, A2, A3, A4, B1, B2, C1 and C2. Plasmids of subclass $\mathrm{A} 1$ (approximately $95 \mathrm{~kb}$ ) were found in all pv. glycinea strains investigated. Plasmids of classes B and $\mathrm{D}$ were present in most cor $^{+}$isolates, and class $\mathrm{C}$ plasmids (11-15 kb) dominated in cor $^{-}$strains. The small plasmid $\mathrm{pD}(8 \mathrm{~kb})$ was observed in over half of the cor $^{+}$ strains. Plasmids of classes B and D were not detected in

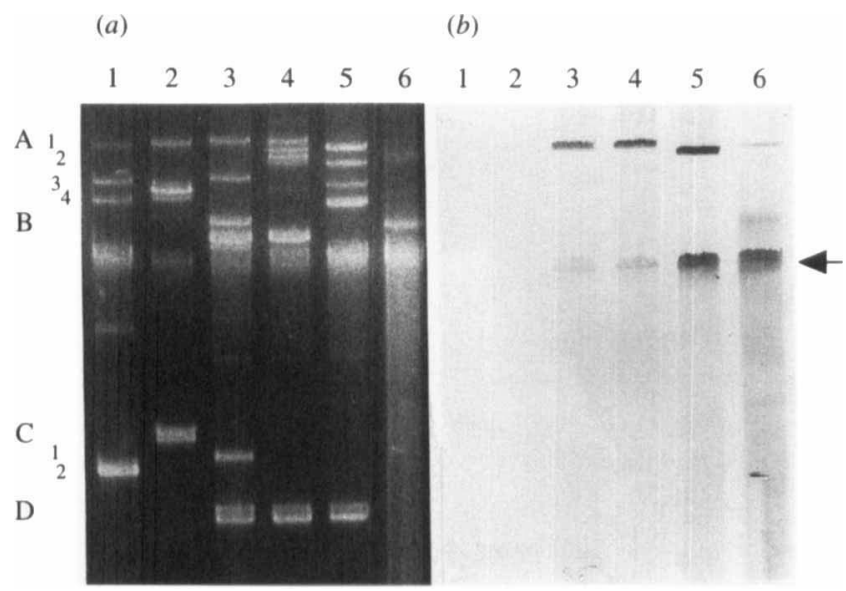

Fig. 1. Plasmid patterns of $P$. syringae pv. glycinea strains and hybridization to plasmid pSAY1 carrying genes for coronatine synthesis. Plasmids were isolated and separated on an agarose gel (a). Homology was detected with digoxigenin-labelled pSAY1 DNA $(b)$. Lanes: 1, Psg 55a/90; 2, Psg 18a/90; 3, Psg 7a/90; 4, Psg 58a/90; 5, $P s g$ S8 $/ 83 ; 6, P_{s g} 49 \mathrm{a} / 90$. The size classes A $(100-70 \mathrm{~kb}), \mathrm{B}(60-30 \mathrm{~kb})$, $\mathrm{C}(15-11 \mathrm{~kb})$ and $\mathrm{D}(8 \mathrm{~kb})$ are indicated. Known plasmids of $P$. syringae pv. glycinea strain PG4180 (Leary et al., 1987) and pv. tomato strain PT23.2 (Bender \& Cooksey, 1986) were used as references for sizing. The arrow indicates fragments of chromosomal and plasmid DNA. The positive signal in this area after hybridization with pSAY1 is derived from broken plasmid DNA migrating in the same size range as chromosomal fragments. 
Table 2. Plasmid profiles of $P$. syringae pv. glycinea strains from field samples

Typical plasmids for group I: A1, A3, B1, B2, C2, D; group II: A1, A2, B2, D; group III: A1, A2, B1; group IV: A1, A3, $\mathrm{C1}$; group V: A1, A3, A4, C2; group VI: A1, A2, A3, A4, D; group VII: A1, A4, C1. +, Presence of plasmids in classes $A(100-70 \mathrm{~kb}), B(60-30 \mathrm{~kb}), \mathrm{C}(15-11 \mathrm{~kb})$ or $\mathrm{D}(8 \mathrm{~kb}) ;++$, double bands in a plasmid class.

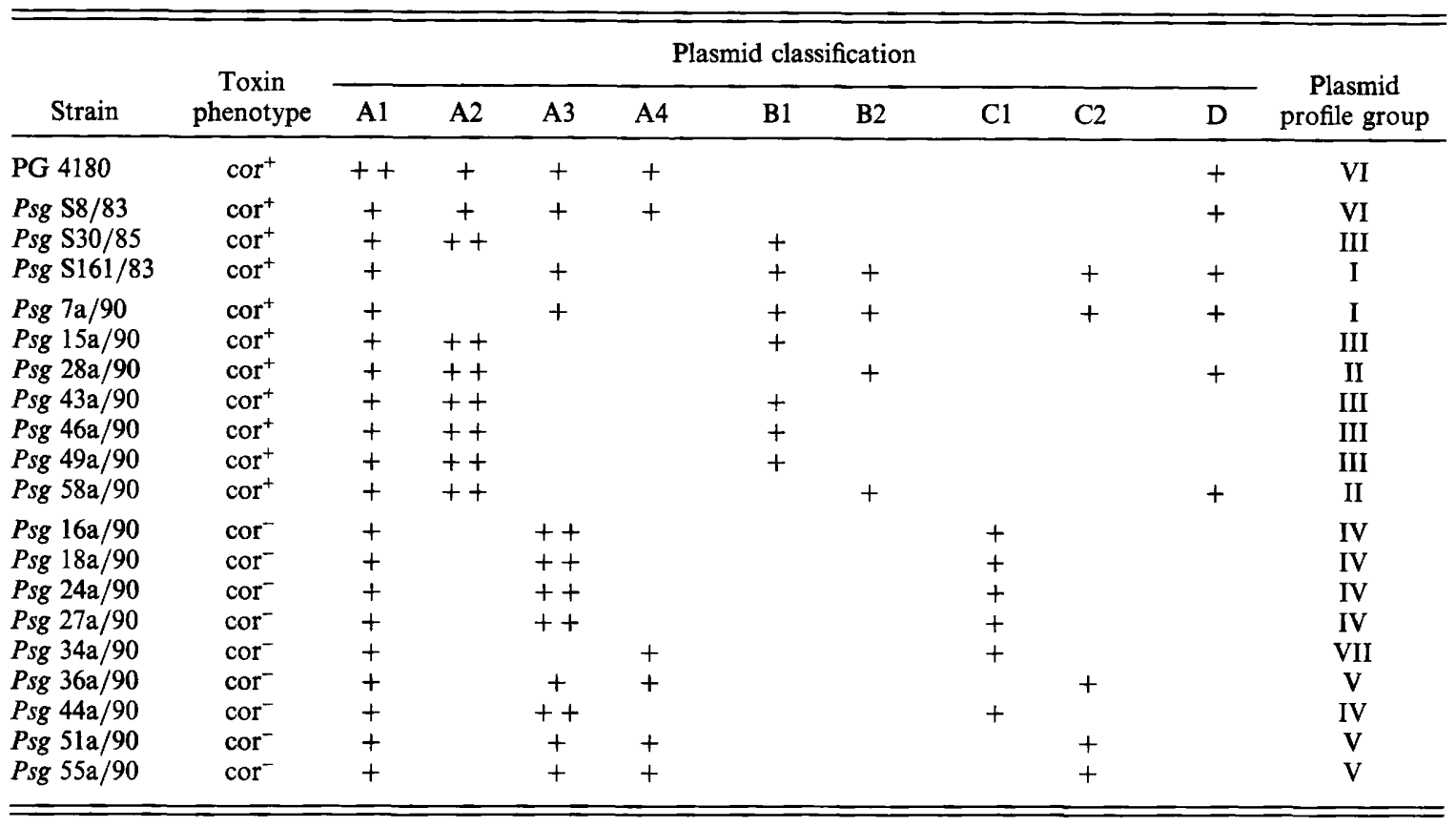

the $\operatorname{cor}^{-}$pv. glycinea isolates obtained from the field. Class C plasmids were present in both cor $^{+}$and cor $^{-}$ strains. The pv. glycinea strains were divided into five groups. The cor ${ }^{+}$strain Psg S8/83 (isolated in 1983) and the cor ${ }^{-}$isolate $P s g$ 34a/90 (isolated in 1990) did not fit into any of the other groups. However, the plasmid pattern of $P s g$ S8/83 was similar to that of strain PG4180, which was isolated in New Zealand in 1975 (Mitchell, 1982). These and strain Psg 34a/90 may be ordered into additional groups VI and VII. All other coronatine-negative strains belonged to two groups distinguishable by their plasmid profiles. The $\operatorname{cor}^{+} \mathrm{pv}$. glycinea isolates were more diverse. Group III contained plasmids of size classes A and B and was dominant in the 1990 isolation (Table 2). When strains isolated from the same field but from different seasons were compared, a conservation of plasmid pattern was found for the cor $^{+}$ strains $P$ sg S161/83 and Psg 7a/90, which were isolated in 1983 and 1990, respectively, and for cor $^{+}$Psg S30/85 and Psg 15a/90 isolated in 1985 and 1990, respectively. Thus, members of groups I and III were found in more than one growing season.

Copper resistance of the isolated $P$. syringae pv. glycinea isolates

All 19 pv. glycinea isolates were tested for growth on solid medium containing $\mathrm{CuSO}_{4}$ (Table 1). Both cor ${ }^{+}$ and cor $^{-}$isolates of pv. glycinea grew well on plates containing $0.4 \mathrm{mM}^{-\mathrm{CuSO}_{4}}$. $\mathrm{CuSO}_{4}$ at $0.6 \mathrm{~mm}$ inhibited all cor $^{-}$strains, except the cor $^{-}$isolate $34 \mathrm{a} / 90$, which grew on plates with $0.6 \mathrm{~mm}$ but not with $1.2 \mathrm{mM}^{-\mathrm{CuSO}_{4}}$. No spontaneous change in copper sensitivity of cor $^{-}$strains was observed. All cor ${ }^{+}$pv. glycinea strains grew well on agar containing $2 \mathrm{~mm}-\mathrm{CuSO}_{4}$. No attempts have yet been made to produce copper-sensitive mutants in order to correlate them to coronatine production. When plasmid p4180A was transferred into $P$. syringae pv. syringae PS61 (Young, 1991), neither PS61 nor PS61(p4180A) grew on standard I agar containing $2.0 \mathrm{mM}-\mathrm{CuSO}_{4}$ but PS61(p4180A) produced coronatine while strain PS61 did not. This result indicates that copper resistance and coronatine production are not linked on p4180A in P. syringae pv. glycinea PG4180.

\section{Race determination}

The race affiliation of the isolated $P$. syringae pv. glycinea strains was examined by investigating their interaction with eight different soybean cultivars (Table 3 ). This differential series of soybean cultivars was also inoculated with known pv. glycinea races from the bacterial culture collection in Göttingen (GSPB). All cor $^{+}$strains produced disease symptoms on eight cultivars and were therefore classified as race 4 . These strains could be separated from reference strain GSPB 1201 (race 2), 
Table 3. Race typing of field isolates of P. syringae pv. glycinea

$\mathrm{C}$, Susceptible (compatible) reaction; I, incompatible reaction (HR); GSPB, strains used as race specific reference strains; ud, strains undefined in race affiliation.

\begin{tabular}{|c|c|c|c|c|c|c|c|c|c|}
\hline \multirow[b]{2}{*}{ Strains } & \multicolumn{8}{|c|}{ Reaction of soybean cultivars } & \multirow[b]{2}{*}{ Race } \\
\hline & Acme & Bicentennial & Chippewa & Flambeau & Harosoy & Merrit & Norchief & Peking & \\
\hline GSPB 1835 & $\mathrm{C}$ & $\mathrm{C}$ & I & C & I & I & I & $\mathrm{C}$ & 1 \\
\hline GSPB 1201 & $\mathrm{C}$ & $\mathrm{C}$ & $\mathrm{C}$ & $\mathrm{C}$ & $\mathrm{C}$ & $\mathrm{C}$ & C & C & $2^{*}$ \\
\hline GSPB 1971 & $\mathrm{C}$ & $\mathrm{C}$ & $\mathrm{C}$ & $\mathrm{C}$ & $\mathrm{C}$ & $\mathrm{C}$ & $\mathrm{C}$ & $\mathrm{C}$ & 4 \\
\hline GSPB 1837 & I & I & I & I & C & C & I & $\mathrm{C}$ & 5 \\
\hline GSPB 1974 & I & I & I & $\mathrm{C}$ & I & I & $\mathrm{C}$ & I & 6 \\
\hline GSPB 2004 & I & I & $\mathrm{C}$ & I & $\mathrm{C}$ & $\mathrm{C}$ & I & I & 9 \\
\hline GSPB 1834 & I & $\mathrm{C}$ & I & I & I & $\mathrm{C}$ & I & I & $0^{*}$ \\
\hline GSPB 1997 & I & I & I & I & $\mathrm{C}$ & $\mathrm{C}$ & I & $\mathrm{C}$ & $\mathrm{X}$ \\
\hline All cor $^{+}$pv. glycinea isolates & $\mathrm{C}$ & $\mathrm{C}$ & $\mathrm{C}$ & $\mathrm{C}$ & $\mathrm{C}$ & C & $\mathrm{C}$ & $\mathrm{C}$ & 4 \\
\hline $\begin{array}{l}\text { cor }^{-} \text {pv. glycinea isolates: } \\
16 \mathrm{a} / 90,18 \mathrm{a} / 90,24 \mathrm{a} / 90 \\
27 \mathrm{a} / 90,44 \mathrm{a} / 90\end{array}$ & I & $\mathbf{I}$ & $\mathrm{C}$ & I & $\mathrm{C}$ & $\mathrm{C}$ & I & I & 9 \\
\hline $\begin{array}{c}\operatorname{cor}^{-} \text {pv. glycinea isolates: } \\
36 \mathrm{a} / 90,51 \mathrm{a} / 90,55 \mathrm{a} / 90\end{array}$ & I & $\mathrm{C}$ & I & I & I & $\mathbf{C}$ & $\mathrm{C}$ & $\mathbf{I}$ & ud \\
\hline cor $^{-}$isolate Psg $34 \mathrm{a} / 90$ & I & I & $\mathrm{C}$ & I & $\mathrm{C}$ & I & $\mathrm{C}$ & I & ud \\
\hline
\end{tabular}

* Causes browning on agar media.

which shows the same incompatibility/susceptibility scheme as race 4 , by the absence of browning on standard I nutrient agar or on King's medium B agar. This browning effect is typical for members of races 2 and 0 . The reaction of the soybean cultivars to the cor pv. glycinea strains corresponded to the classification scheme obtained by plasmid profiles. Group IV consisted of strains Psg 16a/90, Psg 18a/90, Psg 24a/90, Psg 27a/90 and $P s g$ 44a/90, and induced a hypersensitive reaction on cultivars Acme, Bicentennial, Flambeau and Norchief, a reaction pattern which is typical for race 9. These strains originated from soybean cv. Maple Arrow, which is susceptible to race 4 and race 9 , but not to the other races. Three cor ${ }^{-}$strains (GSPB 1995, 1996, 2034) were ordered into race 4 by their reaction to the soybean cultivars used for race differentiation (Table 1).

Coronatine-negative isolates $P s g$ 36a/90, Psg 51a/90, and $P_{s g} 55 \mathrm{a} / 90$ were characterized by HR induction on plants of cvs Acme, Chippewa, Flambeau and Harosoy. These strains could not be classified as members of any known races of pv. glycinea.

\section{Homology of P. glycinea pv. glycinea plasmid DNA to genes involved in coronatine synthesis}

Recently, Bender et al. (1991) cloned a DNA fragment which contains genes involved in coronatine synthesis. In the present study, the cosmid clone pSAY1 was used as a probe to find possible plasmid DNA homology among the isolated pv. glycinea strains. When intact plasmid
DNA was probed with digoxigenin-labelled pSAY1, the largest plasmid band in each cor ${ }^{+}$strain hybridized to the probe, whereas no hybridization signal was detected for plasmids contained in cor $^{-}$strains (Fig. $1 b$ ). pSAY1 did not hybridize to $\mathrm{pPG} 1$, an $8 \mathrm{~kb}$ plasmid of size class $\mathrm{D}$ which was previously suggested to play a role in coronatine production (Leary et al., 1987), nor to plasmids in classes other than A1. When pSAY1 was probed to SstI-digested plasmid DNA of strains isolated in the present study, hybridization occurred to six Sst $\mathrm{I}$ fragments in the cor ${ }^{+}$isolates which were similar in size to six $S s t$ I fragments contained in pSAY1 (8.3, 5.4, 4.6, $3.7,3.3$ and $2.5 \mathrm{~kb}$ ). In contrast, no homology to DNA fragments from plasmid DNA of cor $^{-}$strains was observed.

Furthermore, plasmid DNA of several pv. glycinea isolates was digested with BamHI and probed with pSAY1. For strain $P_{s g} 7 \mathrm{a} / 90$ six fragments of $13.0,10 \cdot 0$, $7 \cdot 9,6 \cdot 0,4.7$ and $3.3 \mathrm{~kb}$ hybridized with the probe (Fig. 2). Since the construction of pSAY1 resulted in loss of the BamHI sites of the vector's polycloning site (C. Bender, personal communication), it was not possible to resolve the bordering insertion in pSAY1 by digestion with this enzyme (Fig. 2, lane 3). The fragments of 13 and $10 \mathrm{~kb}$ represent the border fragments of plasmid pAl of $P s g$ $7 \mathrm{a} / 90$. These fragments were found in all cor ${ }^{+}$strains isolated in 1990, but not in strain Psg S8/83, which was isolated in 1983. BamHI-digested plasmid DNA from PG4180 showed a hybridization pattern identical to $P s g$ S8/83 when probed with pSAY1. Southern blot analysis 


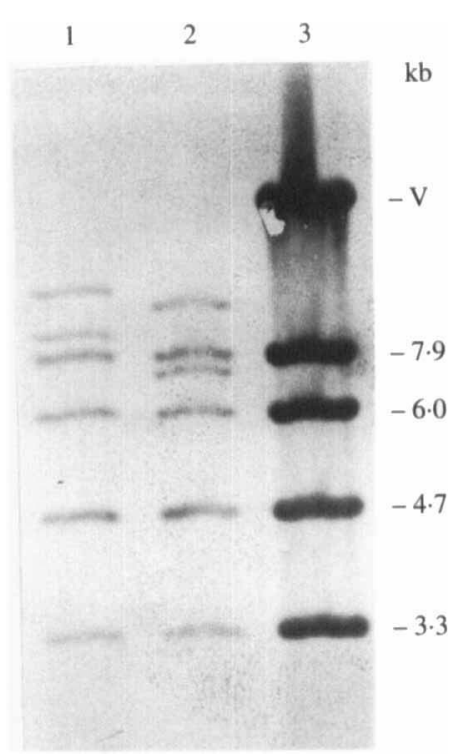

Fig. 2. Restriction fragment length polymorphism of BamHI-digested plasmid DNA of two coronatine producing $P$. syringae pv. glycinea strains from field samples. The probe was digoxigenin-labelled DNA of plasmid pSAY1. Lanes: 1, Psg 7a/90; 2, Psg S8/83; 3, pSAY1. The sizes of internal BamHI fragments are indicated; $V$, position of vector DNA.

indicated that BamHI fragments adjacent to the polylinker in the pSAY1 insert were 7.5 and $12 \mathrm{~kb}$ in the coronatine plasmids indigenous to PG4180 and Psg
S8/83. Therefore, restriction fragment polymorphisms were found which distinguished the pv. glycinea isolates of 1990 from Psg S8/83 and PG4180. Since none of the plasmids of the cor $^{-} P s g$ strains showed hybridization signals to pSAY1, chromosomal DNA of those strains was probed. No clear signal was observed, which indicates that coronatine synthesis genes are not present in these strains.

\section{Differentiation of $\operatorname{cor}^{+}$and $\operatorname{cor}^{-} P$. syringae pv. glycinea strains by PCR}

The amplification reaction was carried out with chromosomal DNA of nine cor $^{+}$and nine cor $^{-}$pv. glycinea field isolates. For these strains the Tn5-derived primer give rise to the amplification of four distinct bands migrating at $3.4 \mathrm{~kb}, 2.7 \mathrm{~kb}, 1.6 \mathrm{~kb}$ and $1 \mathrm{~kb}$ in both types of strain (Fig. 3). An additional band of $4 \mathrm{~kb}$ was observed in the cor $^{-}$isolates $P_{s g}$ 36a/90, Psg 51a/90 and Psg 55a/90. The cor $^{+}$pv. glycinea strains produced a characteristic signal at $5 \mathrm{~kb}$, which was not observed for the cor isolates. This implies that a $5 \mathrm{~kb}$ band is specific for pv. glycinea derivatives which are copper resistant and produce the phytotoxin coronatine. Furthermore, the PCR-amplified signals from $P$. syringae pv. glycinea were different from those of $P$. syringae pvs tomato, syringae, phaseolicola or morsprunorum, which did not produce the $5 \mathrm{~kb}$ band (S. Bereswill \& K. Geider, unpublished data).

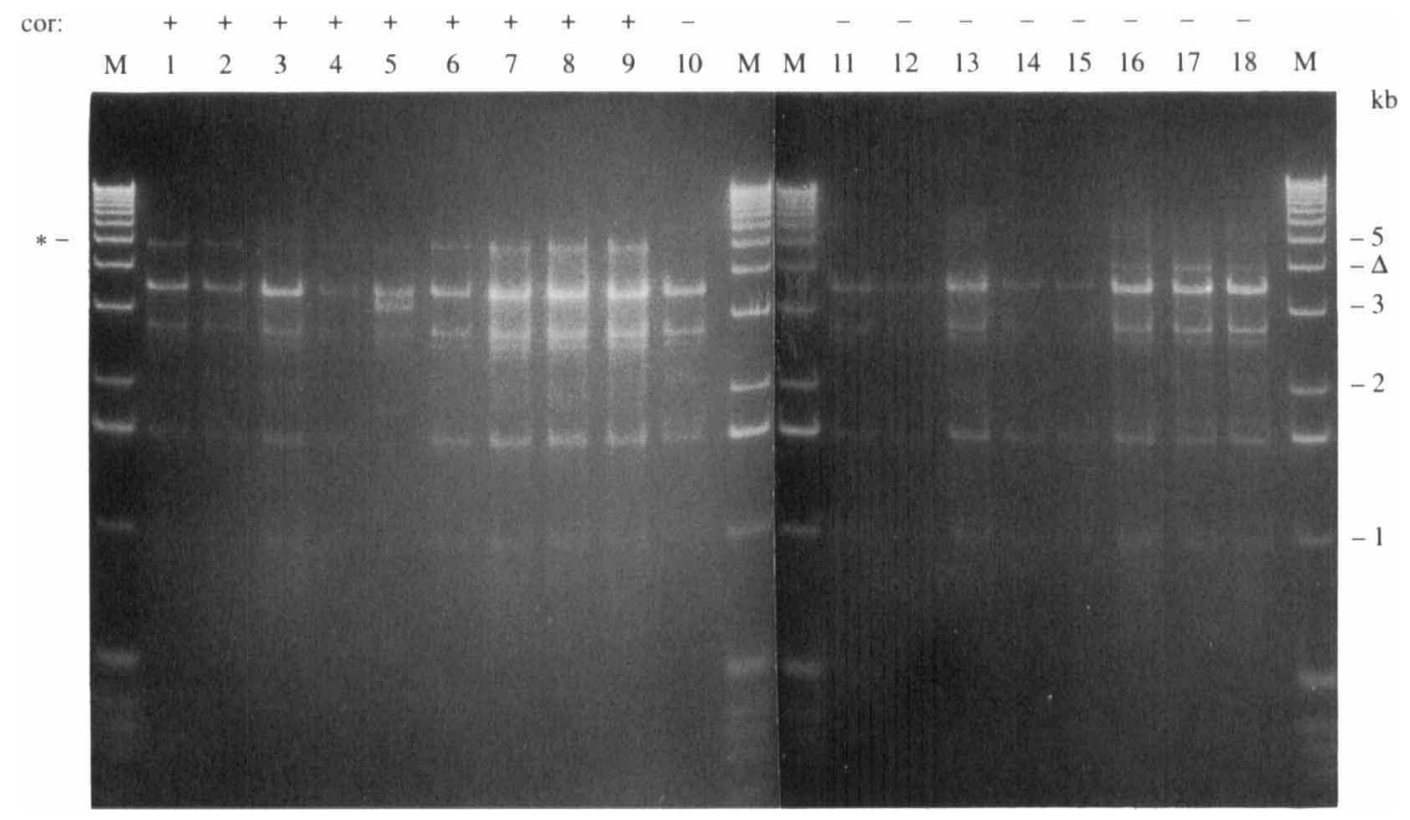

Fig. 3. PCR analysis of $P$. syringae pv. glycinea DNA with a single primer. Lanes $1-9$ show coronatine-positive strains and lanes $10-18$ coronatine-negative strains. Lanes: 1 , Psg 7a/90; 2, Psg S161/83; 3, Psg S8/83; 4, Psg S30/85; 5, Psg 15a/90; 6, Psg 43a/90; 7, Psg 46a/90; 8, Psg 28a/90; 9, Psg 58a/90; 10, Psg 34a/90;11, Psg 16a/90; 12, Psg 18a/90; 13, Psg 24a/90; 14, Psg 27a/90;15, Psg 44a/90; 16, Psg 36a/90; 17, Psg 51a/90;18, Psg 55a/90; M, 1 kb ladder marker DNA (the size of some fragments is indicated), *, A $5 \mathrm{~kb}$ band, characteristic of coronatine-producing strains; $\Delta$, a $4 \mathrm{~kb}$ band, produced by some coronatine-negative strains. 


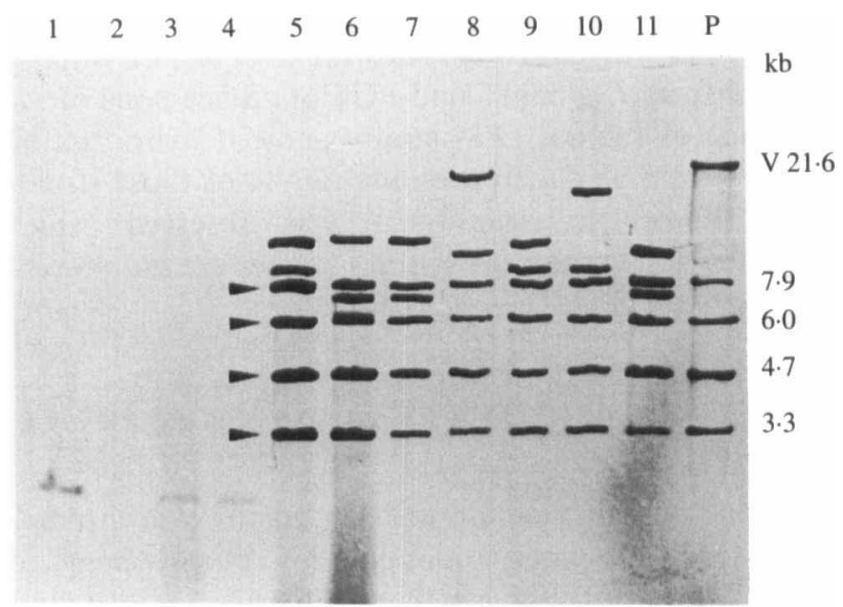

Fig. 4. RFLP pattern of BamHI-digested plasmid DNA from $P$. syringae pv. glycinea. Strains without coronatine synthesis are shown in lanes $1-4$, positive strains in lanes $5-11$. The sizes $(\mathrm{kb})$ of BamHI fragments of plasmid pSAY1 are indicated on the right and by arrowheads. Lanes: 1, GSPB 1561; 2, GSPB 2003; 3, Psg 51a/90; 4, Psg 44a/90; 5, GSPB 1974 (race 6); 6, GSPB 2033; 7, GSPB 1545; 8, GSPB $1971 ; 9$, Psg 7a/90; 10, GSPB 2002; 11, GSPB 1988; P, pSAY1. V, Vector DNA.

\section{Molecular characterization of $P$. syringae pv. glycinea strains from a culture collection}

Eight strains which were used as reference for pv. glycinea races and 19 additional pv. glycinea isolates from different geographic origins and isolation dates, were assayed for coronatine production, copper resistance, and homology to pSAY1 (Table 1). The race reference strains and strain PG4180, which is well characterized for its molecular biology, were considered to be 'pathotypes'. The correlation between coronatine synthesis and copper resistance which was shown for field isolates was also confirmed for strains from the culture collection. Out of 27 GSPB strains, 13 produced hypertrophic outgrowth on potato tissue and grew on agar with $2 \mathrm{~mm}-\mathrm{CuSO}_{4}$. All 13 isolates were previously classified into race 4 (11 strains) and race 6 (2 strains) (Abo-Moch et al., 1991). When plasmid DNA contained in these strains was digested with SstI and probed with pSAY1 the bands hybridized to the coronatine-specific probe producing the six fragments of the plasmid insertion. However, three race 4 strains which were isolated in France (GSPB 1561), Italy (GSPB 1995) and Serbia (GSPB 1996) were sensitive to copper ions and did not produce coronatine in detectable amounts. The remaining 11 cor $^{-}$strains, which belonged to races 1,2 , $5,9,0$ and $X$, were copper-sensitive and did not show homology to pSAY1. pSAY1 hybridized to bands of similar size in the BamHI-digested cor $^{+}$GSPB strains (Fig. 4). Polymorphisms observed between strains probably indicated variability in the size of fragments which

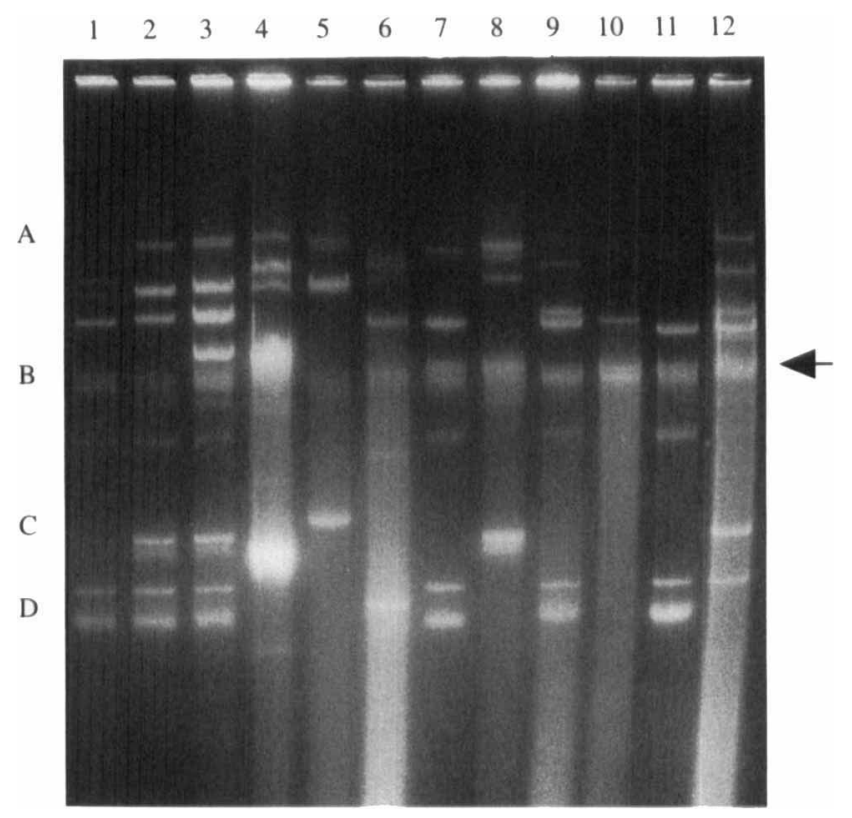

Fig. 5. Plasmid profiles of various $P$. syringae pv. glycinea strains derived from the GSPB culture collection. Plasmids were isolated and separated on an agarose gel. Lanes 1-5, cor $^{-}$strains; lanes 6-12, cor $^{+}$ strains. Lanes: 1, GSPB 1997 (race X); 2, GSPB 2034 (race 4); 3, GSPB 2003 (race 9); 4, Psg 51a/90; 5, Psg 44a/90 (race 9); 6, GSPB 1545 (race 4); 7, GSPB 1988 (race 4); 8, GSPB 1974 (race 6); 9, GSPB 1971 (race 4); 10, Psg 49a/90; 11, Psg 58a/90; 12, Psg 7a/90. Letters A to D indicate plasmid size classes according to Table 2 . The arrow indicates fragments of chromosomal and plasmid DNA.

flank the coronatine region. These polymorphisms were not due to race specificity since GSPB 1974, which is a race 6 isolate, showed a hybridization pattern similar to a race 4 strain, pv. glycinea $7 \mathrm{a} / 90$ (Fig. 4, lanes 5 and 9).

The plasmid patterns in the pv. glycinea strains from the culture collection differed from those found in the field isolates (Fig. 5). Plasmids of subclass A1 were found in all pv. glycinea strains tested. Plasmids of size class B (30-60 kb) which were typical for cor $^{+}$and copperresistant pv. glycinea strains, also occurred in cor $^{-}$and copper-sensitive GSPB isolates. Interestingly, the $8 \mathrm{~kb}$ plasmid (class D) occurred in cor $^{+}$and cor ${ }^{-}$strains. It was claimed previously to be specific for coronatine producing pv. glycinea strains (Leary et al., 1987). No correlation between race and plasmid profiles could be found for the GSPB isolates (Fig. 5, lanes 3 and 5).

\section{Discussion}

Strains of $P$. syringae pv. glycinea were characterized for coronatine production, copper resistance, and race affiliation. Coronatine synthesis as well as copper resistance have been genetically investigated in $P$. syringae pv. tomato strain PT23.2 (Bender \& Cooksey, 1986, 1987; Bender et al., 1989; Mellano \& Cooksey, 
1988). The DNA regions responsible for these traits are located on plasmids designated as pPT23A (coronatine synthesis), pPT23C (copper resistance) and pPT23D (copper resistance, cop operon). The localization of genes encoding these properties on different plasmids suggests an independent evolution of copper resistance in $P$. syringae pathovars synthesizing coronatine. Results obtained in the present study with $\mathrm{p} 4180 \mathrm{~A}$ support this hypothesis. Upon acquisition of $\mathrm{p} 4180 \mathrm{~A}, P$. syringae $\mathrm{pv}$. syringae PS61 acquired the ability to synthesize coronatine (Young, 1991), but did not become copperresistant. DNA hybridization experiments were conducted in the present study using pSAY1, which contains a $30 \mathrm{~kb}$ insert from the $101 \mathrm{~kb}$ plasmid pPT23A of $P$. syringae pv. tomato strain PT23.2. The insert DNA in pSAY1 was shown to be required for coronatine production in $\mathrm{pv}$. tomato and restored phytotoxin synthesis to coronatine-negative Tn5 mutants of PT23.2. Furthermore, the insert DNA of pSAY1 hybridized to large plasmids in other coronatine-producing pathovars of $P$. syringae, indicating a conservation of this DNA region in many producers (Bender et al., 1991). The homology also found for pv. glycinea indicated a strong conservation of coronatine synthesis genes in plasmid DNA of coronatine-producing isolates. For digests with two restriction enzymes (SstI and BamHI) we observed hybridizing fragments identical to those contained in pSAY1. Hybridization of pSAY1 to BamHI-digested plasmid revealed distinct polymorphisms for pv. glycinea isolates from different regions or years of isolation. In a previous report, homology of genes required for coronatine synthesis was demonstrated for four coronatineproducing pathovars of $P$. syringae (Bender et al., 1991). Coronatine production and copper resistance were correlated for all pv. glycinea strains investigated. However, results obtained with $\mathrm{p} 4180 \mathrm{~A}$ indicate that the genes responsible for these properties are unlikely to be linked on a single plasmid. A mutual benefit to the plasmids deriving from co-residence in the same cell could still be a reason for coevolution of copper resistance and coronatine production in $P$. syringae pv. glycinea. Approximately one-third of the field isolates did not produce coronatine. These were all coppersensitive and their plasmid and chromosomal DNA did not hybridize to plasmid pSAY1. A possible explanation for their copper-sensitivity is the presence of a plasmid incompatible with plasmids encoding copper resistance in cor $^{+}$strains. Incompatibility in cor $^{-}$strains may also occur for the plasmid with genes for coronatine synthesis.

In the present study, the classification of cor $^{+}$and cor strains in $P$. syringae pv. glycinea was achieved both by pathogenicity on soybean and by PCR analysis with a random primer. Common bands were generated by PCR in all pv. glycinea strains, and an additional band was generated in all coronatine-producing strains. Randomprimed PCR analysis has also been used to distinguish aggressive and non-aggressive strains of Leptosphaeria maculans (Schäfer \& Wöstemeyer, 1992).

The plasmid pattern of the field isolates was determined and used for classification of the strains. They were ordered into six groups according to their plasmid profile. Denny (1988) used a similar approach to classify $P$. syringae pv. tomato. He found diversity for the plasmid profiles and similarity in other properties like phage sensitivity, fatty acid composition and sugar catabolism. A more homogeneous profile was found by Bender \& Cooksey (1986) for pv. tomato strains isolated from Southern California, USA. DNA fingerprint analysis of plasmid DNA of plant pathogenic bacteria has revealed heterogeneity not only for $P$. syringae pv. pisi but also for pv. glycinea strains (King, 1988).

A classical criterion for the grouping of pv. glycinea strains is the determination of races. All of the coronatine-producing field isolates investigated in the current study belonged to race 4 . The non-producing strains were assigned to race 9 or an undefined race reaction pattern. Since race 4 strains are the most common in Europe (Abo-Moch et al., 1991), their ability to produce coronatine might favour distribution under natural conditions.

Strains from an established culture collection also showed a correlation between coronatine synthesis and copper resistance. These strains belonged to races 4 and 6 (Abo-Moch et al., 1991). The heterogeneous history of their isolation is reflected by a remarkable number of RFLPs observed for the region bordering the biosynthesis cluster for coronatine synthesis. The plasmid and chromosomal DNA of coronatine-negative strains did not hybridize to probe pSAY1, indicating the specificity of this probe for detection of coronatineproducing pv. glycinea isolates. The coronatine nonproducing strains were heterogeneous in their race affiliation. The plasmid profiles of the GSPB strains were complex and could not be used for classification. On the other hand, random-primed PCR analysis resembles the fingerprinting of genomic DNA and can be used for differentiation of bacterial species and pathovars (Welsh \& McClelland, 1990; S. Bereswill \& K. Geider, unpublished data). The PCR bands confirmed the data about strains with respect to coronatine synthesis and the classification of the isolates described to be pv. glycinea. It seems reasonable to assume that $\operatorname{cor}^{+}$and $\operatorname{cor}^{-}$strains may occur in a single lesion of a diseased soybean leaf. In this study, we avoided isolating more than one strain from each lesion. These independently derived strains were unambigiously identified as $P$. syringae pv. glycinea and differ in production of the phytotoxin coronatine. Further investigations are required to determine the 
properties of cor ${ }^{+}$and cor ${ }^{-}$strains isolated from soybean lesions or of cor $^{-}$mutants in order to address the question as to the advantage of either phenotype for certain stages in the development of bacterial blight on soybean under natural conditions.

We thank Dr C. L. Bender (Department of Plant Pathology, Oklahoma State University, Stillwater, USA) for generously providing cosmid pSAY1, for unpublished data, for fruitful discussions and very helpful comments on the manuscript. We are also grateful to $\mathrm{Dr}$ K. Rudolph, University of Göttingen, for the gift of bacterial cultures.

\section{References}

ABo-Moch, F., MaVRidis, A. \& RUdOLPH, K. (1991). Occurrence of races of Pseudomonas syringae pv. glycinea in Europe and their capability to produce coronatine. Proceedings of the 4th International Working Group on Pseudomonas syringae Pathovars, pp. 227-233.

BENDER, C. L. \& COOKSEY, D. A. (1986). Indigenous plasmids in Pseudomonas syringae pv. tomato: conjugative transfer and role in copper resistance. Journal of Bacteriology 165, 534-541.

BENDER, C. L. \& COOKSEY, D. A. (1987). Molecular cloning of copper resistance genes from Pseudomonas syringae pv. tomato. Journal of Bacteriology 169, 470-474.

Bender, C. L., Stone, H. E., Sims, J. J. \& Cooksey, D. A. (1987). Reduced pathogen fitness of Pseudomonas syringae pv. tomato $\operatorname{Tn} 5$ mutants defective in coronatine production. Physiological and Molecular Plant Pathology 30, 273-283.

Bender, C. L., Malvick, D. K. \& Mitchell, R. E. (1989). Plasmidmediated production of the phytotoxin coronatine in Pseudomonas syringae pv. tomato. Journal of Bacteriology 171, 807-812.

Bender, C. L., Young, S. A. \& MrTChell, R. E. (1991). Conservation of plasmid DNA sequences in coronatine producing pathovars of Pseudomonas syringae. Applied and Environmental Microbiology 57, 993-999.

BRADBURY, J. F. (1988). Identification of cultivable bacteria from plants and plant tissue cultures by use of simple classical methods. Acta Horticulture 225, 27-37.

CHA, J. S. \& COOKSEY, D. A. (1991). Copper resistance in Pseudomonas syringae mediated by periplasmic and outer membrane proteins. Proceedings of the National Academy of Sciences of the United States of America 88, 8915-8919.

Cook, A. A. \& STALl, R. E. (1982). Distribution of races of Xanthomonas campestris pathogenic on pepper. Plant Disease 66, 388-389.

Cross, J. E., Kennedy, B. W., Lampbert, J. W. \& Cooper, R. L. (1966). Pathogenic races of the bacterial blight pathogen of soybean, Pseudomonas glycinea. Plant Disease Reports 50, 557-560.

DenNy, T. P. (1988). Phenotypic diversity in Pseudomonas syringae pv tomato. Journal of General Microbiology 134, 1939-1948.

FETT, W. F. \& SEQUEIRA, L. (1981). Further characterization of the physiologic races of Pseudomonas glycinea. Canadian Journal of Botany 59, 283-287.

Gnanamanickam, S. S., Starratt, A. N. \& Ward, E. W. B. (1982). Coronatine production in vitro and in planta and its relation to symptom development in bacterial blight of soybean. Canadian Journal of Botany 60, 645-650.

Hugh, R. \& Leirson, R. (1953). The taxonomic significance of fermentative versus oxidative metabolism of carbohydrates by various gram-negative bacteria. Journal of Bacteriology 66, 24-26.

KeEN, N. T. \& Staskawicz, B. (1988). Host range determinants in plant pathogens and symbionts. Annual Review of Microbiology 42, $421-440$.

King, E. O., WARD, M. K. \& Raney, D. E. (1954). Two simple media for the demonstration of pyocyanin and fluorescin. Journal of Laboratory and Clinical Medicine 44, 301-307.

KING, G. J. (1988). A DNA fingerprinting system for phytopathogenic pseudomonads. Mededelingen van de Faculteit Landbouwwetenschappen Rijksuniversiteit Gent 53, 1679-1684.

Leary, J. V., Willis, J. W. \& Trollinger, D. (1987). Molecular genetics of coronatine production in Pseudomonas syringae pv. glycinea. In Plant Pathogenic Bacteria, pp. 498-508. Edited by E. L. Civerolo, D. Colmer, R. E. Davis \& A. G. Gillaspie. Dordrecht: Martinus Nijhof Publications.

Lelliott, R. A., Billing, E. \& Hayward, A. C. (1966). A determinative scheme for the fluorescent plant pathogenic Pseudomonads. Journal of Applied Bacteriology 29, 470-480.

MA, S. W., MoRrIS, V. L. \& Cuppels, D. A. (1991). Characterization of a DNA region required for production of the phytotoxin coronatine by Pseudomonas syringae pv tomato. Molecular PlantMicrobe Interactions 4, 69-74.

Maniatis, T., Fritsch, E. F. \& SAmbrooK, J. (1982). Molecular Cloning: A Laboratory Manual. Cold Spring Harbor, NY: Cold Spring Harbor Laboratory.

Martin, G. B., Williams, J. G. K. \& Tanksley, S. D. (1991). Rapid identification of markers linked to a Pseudomonas resistance gene in tomato by using random primers and near-isogenic lines. Proceedings of the National Academy of Sciences of the United States of America 88, 2336-2340.

Mellano, A. M. \& Cooksey, D. A (1988). Nucleotide sequence and organization of copper resistance genes from Pseudomonas syringae pv. tomato. Journal of Bacteriology 170, 2879-2883.

MiTCHELL, R. E. (1982). Coronatine production by some phytopathogenic pseudomonads. Physiological Plant Pathology 20, 83-89.

MitCHELL, R. E. (1985). Coronatine biosynthesis: incorporation of $\mathrm{L}-\left[\mathrm{U}-{ }^{14} \mathrm{C}\right]$ isoleucine and $\mathrm{L}-\left[\mathrm{U}-{ }^{14} \mathrm{C}\right]$ threonine into the 1-amino-1carboxy-2-ethylcyclopropyl moiety. Phytochemistry 24, 247-249.

MITCHELL, R. E. (1991). Coronatine analogs produced by Xanthomonas campestris pv. phormicola. Phytochemistry 30, 3917-3920.

Nishiyama, K., SaKai, R., EzuKa, A., Ichihara, A., Shiraishi, K., Ogasawara, M., Sato, H. \& Sakamura, S. (1976). Phytotoxic effect of coronatine produced by Pseudomonas coronafaciens var. atropurpurea on leaves of Italian ryegrass. Annals of the Phytopathological Society of Japan 42, 613-614.

PARRY, R. J. \& MAFOTI, R. (1986), Biosynthesis of coronatine, a novel polyketide. Journal of the American Chemical Society 108, 4681-4682.

Parri, R. J., Lin, M. T., Walker, A. E. \& Mhaskar, S. (1991). The biosynthesis of coronatine: investigations of the biosynthesis of coronamic acid. Journal of the American Chemical Society 113, $1849-1850$.

Sakai, R., Nishiyama, K., Ichihara, A., Shiraishi, K. \& Sakamura, S. (1979). Studies on the mechanism of physiological activity of coronatine. Effect of coronatine on cell wall extensibility and expansion of potato tuber tissue. Annals of the Phytopathological Society of Japan 45, 645-653.

Sato, M., Nishiyama, K. \& ShIRata, A. (1983). Involvement of plasmid DNA in the productivity of coronatine by Pseudomonas syringae pv. atropurpurea. Annals of the Phytopathological Society of Japan 49, 522-528.

SCHÄFER, C. \& WöSTEMEYER, J. (1992). Random primer dependent PCR differentiates aggressive from non-aggressive isolates of the oilseed rape Phoma lingam (Leptosphaeria maculans). Journal of Phytopathology 136, 124-136.

STALL, R. E., LOSCHKE, D. C. \& JoNES, J. B. (1986). Linkage of copper resistance and avirulence loci on a self-transmissable plasmid in Xanthomonas campestris pv. vesicatoria. Phytopathology 76, 240-243.

Staskawicz, B. J. \& Panopoulos, N. J. (1979). A rapid and sensitive microbiological assay for phaseolotoxin. Phytopathology 69, 663-666.

Ullrich, M., Geider, K. \& Fritsche, W. (1991). Plasmid patterns of Pseudomonas syringae pv. glycinea strains with or without coronatine production. Proceedings of the 4th International Working Group of Phytopathogenic Pseudomonads, pp. 324-329.

Völksch, B., Bublitz, F. \& Frrtsche, W. (1989). Coronatine production by Pseudomonas syringae pathovars: screening method and capacity of production formation. Journal of Basic Microbiology 29, 463-468. 
Welsh, J. \& MCClelland, M. (1990). Fingerprinting genomes using PCR with arbitrary primers. Nucleic Acids Research 18, 72137218.

Welsh, J., Petersen, C. \& McClelland, M. (1991). Polymorphisms generated by arbitrarily primed PCR in the mouse: application to strain identification and genetic mapping. Nucleic Acids Research 19, 303-306.

Williams, J. G. K., Kubelik, A. R., LivaK, K. J., Rafalski, J. A. \& TINGEY, S. V. (1990). DNA polymorphisms amplified by arbitrary primers are useful as genetic markers. Nucleic Acids Research 18, 6531-6535.

YouNG, S. A. (1991). Isolation of genes involved in coronatine biosynthesis from P. syringae pv. tomato and P. syringae pv. glycinea PG4180. M.S. thesis, Oklahoma State University, USA.

Young, S. A., Park, S. K., Rodgers, C., Mitchell, R. E. \& Bender, C. L. (1992). Physical and functional characterization of the gene cluster encoding the polyketide phytotoxin coronatine in Pseudomonas syringae pv. glycinea. Journal of Bacteriology 174, 1837-1843. 